\title{
The Correlation
}

\section{Between Incidence of}

\section{Metabolic Syndrome and}

\section{Clinical Characteristics in}

\section{Schizophrenia Patients}

\section{ABSTRACT}

The correlation between incidence of metabolic syndrome and sociodemographic and clinical characteristics in schizophrenia patients

Objective: The purpose of this study was to determine the frequency of metabolic syndrome (MetS) in schizophrenia patients who are receiving treatment with antipsychotic drugs and also the sociodemographic and clinical characteristics of schizophrenia patients with MetS

Methods: 111 schizophrenia patients diagnosed on the basis of DSM-IV diagnostic criteria and receiving antipsychotic therapy for at least 3 months were included in the study. MetS was diagnosed on the basis of International Diabetes Fedaration (IDF) diagnostic criteria. Schizophrenia patient groups with and without diagnosed MetS were compared in terms of sociodemographic and clinical characteristics.

Results: MetS was determined in $27 \%$ of the patients. The most commonly determined parameter was elevated waist circumference (65.8\%). The least common parameter was elevated blood pressure $(10.8 \%)$. The waist circumference parameter in women and the blood pressure parameter in men were more frequently determined. No difference was determined between schizophrenia patients with or without MetS in terms of sociodemographic characteristics, schizophrenia subtypes and symptoms or other clinical characteristics.

Conclusion: MetS is a significant problem in schizophrenia patients receiving antipsychotic therapy. Elevated waist circumference is an important parameter in monitoring. The findings in the literature regarding the relationship between MetS and sociodemographic and clinical characteristics are contradictory. No correlation was determined in our study. Further studies are now needed to shed light on this subject. There would seem to be no correlation between MetS and schizophrenia subtypes and symptoms.

Key words: Clinical characteristics, metabolic syndrome, schizophrenia, sociodemographic characteristics

\section{ÖZET}

Şizofreni hastalarında metabolik sendrom sıklığının sosyodemografik ve klinik özelliklerle ilişkisi

Amaç: Bu çalışmada, antipsikotik ilaçlarla tedavi altında olan şizofreni hastalarında metabolik sendrom (MetS) sıklığı ve metabolik sendromlu hastaların sosyodemografik ve klinik özelliklerinin saptanması amaçlanmıştır. Yöntem: DSM-IV tanı kriterlerine göre tanısı konan ve en az 3 aydır antipsikotik tedavi almakta olan 111 șizofreni hastası çalş̧maya alındı. MetS tanısı Uluslararası Diyabet Fedarasyonu (IDF) tanı kriterlerine göre kondu. MetS tanıı konan ve konmayan hasta grupları arasında sosyodemografik ve klinik özellikler açısından karşılaştırma yapild.

Bulgular: Hastaların \%27'sinde MetS saptandı. En sık saptanan kriter, bel çevresi genişliğiydi (\%65.8). Sıklı̆ı en az olan kriter ise kan basıncı yüksekliğiydi (\%10.8). Bel çevresi genişliği kriteri kadınlarda, kan basıncı yüksekliği kriteri ise erkeklerde daha sık karşılandı. MetS'i olan ve olmayan şizofreni hastaları arasında sosyodemografik özellikler, şizofreni tipi, semptomları ve diğer klinik özellikler açııından fark saptanmadı.

Sonuç: Antipsikotik tedavi altında olan şizofreni hastalarında MetS önemli bir sorundur. Bel çevresi genişliği takipte önemli bir kriterdir. Literatürde MetS ile sosyodemografik ve klinik özelliklerin ilişkisine dair bulgular çelişkilidir. Bizim çalışmamızda ilişki saptanmamıştır. Bu konuyu aydınlatmak için daha fazla sayıda çalışmaya intiyaç vardır. MetS ile şizofreni alt tipleri ve şizofreni semptomları ilişkisiz gibi görünmektedir.

Anahtar kelimeler: Klinik özellikler, metabolik sendrom, şizofreni, sosyodemografik özellikler

Address reprint requests to / Yazışma adresi: Assist. Prof. Dr. Gokhan Sarisoy, Ondokuz Mayis University, Faculty of Medicine, Department of Psychiatry, 55200 Samsun - Turkey

Phone / Telefon: +90-362-312-1919

E-mail address / Elektronik posta adresi: gokhansarisoy@gmail.com

Date of receipt / Geliş tarihi: July 30, 2012 / 30 Temmuz 2012

Date of acceptance / Kabul tarihi: September 17, 2012 / 17 Eylül 2012 


\section{INTRODUCTION}

T he most common cause of natural death in patients with schizophrenia is cardiovascular disorders $(1,2)$. Metabolic syndrome (MetS), sets the ground for diabetes and cardiovascular disorders (CVD) by causing some clinical and metabolic problems (3-7). MetS (Syndrome $\mathrm{X}=$ insulin resistance syndrome=dysmetabolic syndrome), was defined firstby Reaven (8). Dyslipidemia, hypertension (HT), obesity, and type 2 diabetes, which are associated with MetS and CVD, are 1.5-2 times more common in schiozphrenia patients when compared with general population $(2,9)$. Sedantary and unhealthy life styles, decreased physical activity, poor diet, smoking, alcohol and susbtance abuse and weight gain due to antipsychotics make schizophrenia patients more liable to MetS by having a negative effect on lipid and glucose metabolisms $(1,2,6,10)$.

There are three definitions of MetS in the literature. Criteria used in these definitions include waist circumference, reduced high density lipoprotein (HDL) level and raised triglycerides (TG), fasting plasma glucose (FPG) and blood pressure (BP). First definition belongs to The US National Cholesterol Education Program Adult Treatment Panel III (NCEP-ATP III). This has been revised by American Heart Association (ATP III A). The two definitions are similar in terms of waist circumference, blood pressure, HDL and TG. The only difference is in FPG measurement. FPG criteria in ATP III is $110 \mathrm{mg} / \mathrm{dL}$ or more while in the ATP III A it is 100 $\mathrm{mg} / \mathrm{dL}$ or higher. The third and most current definition was done by International Diabetes Federation (IDF). Waist circumference is smaller than ATP III and III A; for MetS diagnosis, raised waist circumference is absolutely necessary along with two other positive criteria. Therefore, IDF criteria leads to more MetS diagnosis when compared with ATP III and ATP III A criteria (2).

MetS prevalence is between $13.4 \%$ and $69.3 \%$ per IDF criteria among patients with schizophrenia (1,1131). Several studies did not find gender differences between schizophrenia patients with or without MetS $(1,14,16,19,27,28,32,33)$. However, there are other studies which reported increased MetS prevalence in women $(17,24,25,28-30,35)$ or men (26). While several studies found MetS to be more common in older patients $(1,17,23,27,29-31,35)$, fewer studies reported no age differences $(26,32,36)$. There have been conflicting results regarding age of onset of the disorder $(19,26,27)$, duration of the disorder $(1,24,26,27,29,31,32,34)$, education $(28,31,32)$ and number of hospitalizations $(15,19,32)$. Other studies reported higher body mass index (BMI) in schizophrenia patients with MetS $(30,33,35)$. There were no differences in terms of smoking $(24,26,27,32,36)$.

There were no differences between schizophrenia patients with or without MetS in terms of family history of schizophrenic disorders (27), HT $(19,24,27,29,32)$, dyslipidemia (19) and cerebrovascular disorders (29). While two studies suggested that diabetes and obesity are more common $(24,31)$, results of several studies argued against it $(19,24,27,29,32,36)$. Hägg and colleagues (33), found higher prevalence of CVDs among families of patients with MetS, however, this was not replicated in two other studies $(27,36)$.

The most common criteria fulfilled among schizophrenia patients with MetS is raised waist circumference $(1,19,24,27-29,35-40)$, while the least common was raised FPG level $(28,35,38)$. De Hert and associates (40) suggested that adding FPG measurement to waist circumference was the most sensitive (100\%) method to follow MetS in patients with schizophrenia.

Antipsychotic treatment is one of the most important causes of MetS in patients with schizophrenia. Clozapine, olanzapine and risperidone are the antipsychotics that most commonly cause metabolic syndrome $(1,12,22,30,34,41)$. Risk is lower for amisulpride, aripiprazole, sertindole, ziprasidone, haloperidol and chlorpromazine $(7,12,22,41)$. MetS is more common during multiple antipsychotic use $(35,42)$. Cerit and colleagues (24) reported longer duration of treatment with antipsychotics in schizophrenia patients with MetS, however, other studies did not find any difference $(19,32,36)$.

The aim of this study was to detect prevalence of MetS per IDF criteria among schizophrenia patients who were on a fixed dose of antipsychotic for at least 3 months and to investigate the association of MetS with sociodemographical and clinical features. 


\section{METHOD}

\section{Sample}

The study included 111 consecutive schizophrenia patients who were being followed and treated at Ondokuz Mayis University, Faculty of Medicine, Department of Psychiatry, Psychotic Disorders Unit during September 2006-December 2007 and who were between 18-70 years of age and were on the same antipsychotic at least for the last three months. Schizophrenia diagnosis were made per DSM-IV-TR diagnostic criteria (43). Exclusion criteria were having a comorbid psychiatric disorder, chronic medical disorders (except hypertension and diabetes), pregnancy, alcohol and substance abuse other than nicotine.

\section{Measurement}

Sociodemographical and Clinical Information Form: Sociodemographical information of the patients were in our Psychotic Disorders Unit, sociodemographical, premorbid and familial features are registered in files along with clinical information obtained by detailed interviews conducted with patients and their relatives. Sociodemographical features of the patients were obtained via these files.

\section{Positive and Negative Symptom Scale (PANSS):}

This is a 30-item semi-structured interview including a 7-point severity assessment which was developed by Kay and colleagues (44). Positive symptoms and negative symptoms subscales include seven items each, the remaining sixteen items form general psychopathology subscale. Kostakoglu and associates conducted Turkish validity and reliability studies (45). Symptoms of the patients with schizophrenia during first admission, follow-up and hospitalization were evaluated with PANSS and semi-structured psychosis follow-up form (a form to assess whether schizophrenia symptoms are present) which has been used in our psychosis department. When any symptom (e.g. auditory hallucinations) was detected during follow-up period, that symptom was recognized as positive.

\section{Laboratory Method}

Fasting plasma samples were obtained for FPG, TG, HDL measurements. The measurement was conducted in the biochemistry laboratory of our university. Plasma glucose (kit: Roche/Hitachi Kat. No. 05168791 Lot No: 658833, \%CV:1.7), TG (kit: Roche/Hitachi Kat. No. 05171407 Lot No: 636318, \%CV:0.9) and HDL (kit: Roche/Hitachi Kat. No. 05168805 Lot No: 639540, \%CV:0.6) levels were measured with Roche Hitachi Cobas 8000 autoanalyzer.

Waist circumference and blood pressure measurement: Waist circumference was measured with measuring tape, naked, from the first border of iliac crest. Blood pressure was measured after at least 5 minutes rest and when sitting.

\section{Metabolic Syndrome (MetS) Diagnosis}

MetS diagnosis were made per International Diabetes Federation (IDF) diagnostic criteria (46). The criteria were: waist circumference $(\mathrm{cm})$ men $\geq 94$, women $\geq 80$; blood pressure $(\mathrm{mm} / \mathrm{Hg}) \geq 130 / 85$; $\mathrm{HDL}(\mathrm{mg} / \mathrm{dl}) \mathrm{men}<40$, women $<50$; TG $(\mathrm{mg} / \mathrm{dL}) \geq 150$; FPG $(\mathrm{mg} / \mathrm{dL}) \geq 100$. Increased waist circumference is absolutely necessary along with two other criteria to make MetS diagnosis per IDF criteria. In our study, we accepted blood pressure criteria positive in patients who were on antihypertensive drugs, and plasma glucose criteria positive in patients who were on hyperglycemic treament.

Patients were divided into two groups on the basis of presence of MetS. Two groups were compared for sociodemographical, familial and clinical features.

This study was conducted in accordance with Helsinki decleration of ethical standards. After detailed explanation of aims of the study, those who volunteered and gave written informed consent (the patient or one of the relatives) were included in the study.

\section{Statistical Analysis}

Statistical analyses were computed with SPSS (Statistics Package for Social Science) software version 16.0. Chi-square test was used to compare categorical 
variables. Since blood pressure criteria, one of the MetS criteria, was not fulfilled in any female patient, Fisher chi-square analysis were used to compare variable in terms of gender. Student-t test was used to compare continuous variables. Categorical varaibles were summarized as percentage, and continuous variables were summarized as mean \pm standard deviation. $p<0.05$ was reported as significant.

\section{RESULTS}

Study group consisted of 111 patients with schizophrenia. Mean age was $34.94 \pm 9.71$ years. $54.9 \%$ of the patients were male, $71 \%$ were single, $62.2 \%$ were from lower socioeconomic level, $56.7 \%$ were living in towns and villages. Mean years of education was $10.42 \pm 4.1$.

Table 1: MetS prevalence per IDF criteria and frequency and percentage of $(+)$ criteria

\begin{tabular}{|c|c|c|c|c|c|c|c|c|}
\hline & All patients $(n=111)$ & $\%$ & $\operatorname{Men}(n=61)$ & $\%$ & Women $(n=50)$ & $\%$ & $\chi^{2}$ & $\mathbf{p}$ \\
\hline MetS prevalence (\%) & 30 & 27.0 & 18 & 29.5 & 12 & 24.0 & 0.19 & 0.66 \\
\hline \multicolumn{9}{|l|}{ Frequency of $(+)$ criteria } \\
\hline Waist circumference & 73 & 65.8 & 34 & 55.7 & 40 & 80.0 & 6.23 & $<0.01$ \\
\hline Reduced HDL & 43 & 38.7 & 21 & 34.4 & 22 & 44.0 & 0.70 & 0.40 \\
\hline Raised TG & 32 & 28.8 & 21 & 34.4 & 11 & 22.0 & 1.51 & 0.22 \\
\hline Raised FPG & 27 & 24.3 & 16 & 26.2 & 11 & 22.0 & 0.09 & 0.77 \\
\hline Raised BP & 12 & 10.8 & 12 & 19.7 & 0 & 0.0 & ---- & $<0.001^{*}$ \\
\hline
\end{tabular}

MetS: Metabolic syndrome, high density lipoprotein (HDL) level and raised triglycerides (TG), fasting plasma glucose (FPG) and blood pressure (BP),

$\chi^{2}$ : Chi-square test, ${ }^{*} \mathrm{p}<0.001$ (Fisher chi-square test)

Table 2: Sociodemographical, familial and clinical features of the groups

\begin{tabular}{|c|c|c|c|c|c|c|}
\hline & \multicolumn{2}{|c|}{ MetS $(+)(n=30)$} & \multicolumn{2}{|c|}{ MetS (-) $(n=81)$} & \multirow[b]{2}{*}{$\chi^{2}$} & \multirow[b]{2}{*}{$\mathbf{p}$} \\
\hline & $\mathbf{n}$ & $\%$ & $\mathbf{n}$ & $\%$ & & \\
\hline \multicolumn{7}{|l|}{ Gender } \\
\hline Male/Female & $18 / 12$ & $60.0-40.0$ & $43 / 38$ & $53.1-46.9$ & 0.19 & 0.66 \\
\hline \multicolumn{7}{|l|}{ Marital status } \\
\hline Single/Married & $23 / 7$ & $76.7-23.3$ & $57 / 24$ & $70.4-29.6$ & 0.17 & 0.68 \\
\hline \multicolumn{7}{|l|}{ Place of residence } \\
\hline City/Town-Village & $12 / 18$ & $40.0-60.0$ & $36 / 45$ & $44.4-55.6$ & 0.04 & 0.84 \\
\hline \multicolumn{7}{|l|}{ Economical status } \\
\hline Poor/Medium-Well & $22 / 8$ & $73.3-26.7$ & $47 / 34$ & $58.0-42.0$ & 1.58 & 0.21 \\
\hline Premorbid history & 18 & 60.0 & 55 & 67.9 & 0.31 & 0.58 \\
\hline \multicolumn{7}{|l|}{ Antipsychotic } \\
\hline Atypical & 21 & 70.0 & 56 & 69.2 & 0.02 & 0.99 \\
\hline Classical & 2 & 6.7 & 6 & 7.4 & & \\
\hline Atypical+Classical & 7 & 23.3 & 19 & 23.5 & & \\
\hline Smoking & 13 & 43.3 & 43 & 53.1 & 0.49 & 0.48 \\
\hline Psychiatric history (first degree relative) & 10 & 33.3 & 23 & 28.4 & 0.07 & 0.79 \\
\hline Psychiatric history (second degree relative) & 11 & 36.7 & 33 & 40.7 & 0.03 & 0.86 \\
\hline Diabetes history (first degree relative) & 11 & 36.7 & 22 & 27.2 & 0.55 & 0.46 \\
\hline CVD history (first degree relative) & 12 & 40.0 & 33 & 40.7 & 0.00 & 1.00 \\
\hline \multirow[t]{2}{*}{$\begin{array}{l}\text { Cerebrovascular disorder history (first } \\
\text { degree relative) }\end{array}$} & 3 & 10.0 & 18 & 22.2 & 1.41 & 0.23 \\
\hline & \multicolumn{2}{|c|}{ Mean \pm SD } & \multicolumn{2}{|c|}{ Mean \pm SD } & $\mathbf{t}$ & $\mathbf{p}$ \\
\hline Age & \multicolumn{2}{|c|}{$35.93 \pm 9.23$} & \multicolumn{2}{|c|}{$34.74 \pm 9.95$} & 0.57 & 0.57 \\
\hline Total years of education & \multicolumn{2}{|c|}{$11.13 \pm 3.56$} & \multicolumn{2}{|c|}{$10.02 \pm 4.24$} & 1.27 & 0.21 \\
\hline Age of onset of illness & \multicolumn{2}{|c|}{$22.63 \pm 7.02$} & \multicolumn{2}{|c|}{$22.79 \pm 7.26$} & -0.10 & 0.92 \\
\hline Duration of illness & \multicolumn{2}{|c|}{$12.87+7.98$} & \multicolumn{2}{|c|}{$11.72+8.33$} & 0.65 & 0.52 \\
\hline Number of hospitalizations & \multicolumn{2}{|c|}{$3.10 \pm 3.32$} & \multicolumn{2}{|c|}{$2.97 \pm 3.15$} & 0.18 & 0.86 \\
\hline Duration of last treatment (months) & \multicolumn{2}{|c|}{$28.13 \pm 33.64$} & \multicolumn{2}{|c|}{$15.84 \pm 20.57$} & 1.88 & 0.07 \\
\hline
\end{tabular}

CVD: Cardiovascular disorder, SD: Standard Deviation, $\chi^{2}$ : Chi-square test, t: Student T test, 
Table 3: Comparison of the groups in terms of schizophrenia subtypes and symptoms

\begin{tabular}{|c|c|c|c|c|c|c|}
\hline & \multicolumn{2}{|c|}{$\operatorname{MetS}(+)(n=30)$} & \multicolumn{2}{|c|}{ MetS (-) $(n=81)$} & \multirow[b]{2}{*}{$\chi^{2}$} & \multirow[b]{2}{*}{$\mathbf{p}$} \\
\hline & $\mathbf{n}$ & $\%$ & $\mathbf{n}$ & $\%$ & & \\
\hline \multicolumn{7}{|l|}{ Schizophrenia subtype } \\
\hline Paranoid & 10 & 33.3 & 30 & 37.0 & \multirow{4}{*}{0.55} & \multirow{4}{*}{0.91} \\
\hline Undifferentiated & 16 & 53.3 & 38 & 46.9 & & \\
\hline Dysorganized & 3 & 10.0 & 11 & 13.6 & & \\
\hline Residual & 1 & 3.3 & 2 & 2.5 & & \\
\hline \multicolumn{7}{|l|}{ Schizophrenia symptoms } \\
\hline Hallucination (auditory) & 27 & 90.0 & 71 & 87.7 & 0.00 & 0.99 \\
\hline Hallucination (other) & 14 & 46.7 & 46 & 56.8 & 0.54 & 0.46 \\
\hline Delusion (grandiosity) & 10 & 33.3 & 16 & 19.8 & 1.56 & 0.21 \\
\hline Delusion (persecution) & 26 & 86.7 & 73 & 90.1 & 0.03 & 0.86 \\
\hline Delusion (control) & 10 & 33.3 & 37 & 45.7 & 0.91 & 0.34 \\
\hline Delusion (thought insertion, broadcast) & 11 & 36.7 & 31 & 38.3 & 0.00 & 1.00 \\
\hline Delusion (other) & 16 & 53.3 & 36 & 44.4 & 0.35 & 0.54 \\
\hline Incoherence & 17 & 56.7 & 39 & 48.1 & 0.34 & 0.56 \\
\hline Agitation & 19 & 63.3 & 46 & 56.8 & 0.16 & 0.69 \\
\hline Depression & 16 & 53.3 & 41 & 50.6 & 0.00 & 0.97 \\
\hline Violence (to people) & 12 & 40.0 & 39 & 48.1 & 0.30 & 0.58 \\
\hline Suicide attempt & 10 & 33.3 & 24 & 29.6 & 0.02 & 0.88 \\
\hline Bizzare behavior & 17 & 56.7 & 46 & 56.8 & 0.00 & 1.00 \\
\hline Hyperactivity & 17 & 56.7 & 43 & 53.1 & 0.01 & 0.90 \\
\hline Violence (property) & 13 & 43.3 & 40 & 49.4 & 0.12 & 0.74 \\
\hline Social withdrawal & 18 & 60.0 & 53 & 65.5 & 0.09 & 0.76 \\
\hline Formal thought disorder & 8 & 26.7 & 22 & 27.2 & 0.00 & 1.00 \\
\hline Unusual thought content & 12 & 40.0 & 41 & 50.6 & 0.61 & 0.43 \\
\hline Impaired role functions & 7 & 23.3 & 33 & 40.7 & 2.17 & 0.14 \\
\hline Blunted affect & 12 & 40.0 & 40 & 49.4 & 0.44 & 0.51 \\
\hline Poor hygiene & 11 & 36.7 & 35 & 43.2 & 0.39 & 0.53 \\
\hline Unusual perception & 10 & 33.3 & 29 & 35.8 & 0.00 & 0.99 \\
\hline
\end{tabular}

$\chi^{2}$ : Chi-square test

$27 \%$ of our patients (men $=29.5 \%$, women $=24 \%$ ) were diagnosed with MetS per International Diabetes Federation (IDF) criteria. There were no gender differences regarding MetS ( $p>0.05)$. The most common criteria was waist circumference $(65.8 \%$ of the patients), while the least common criteria was high blood pressure (10.8\% of the patients). Increased waist circumference was more common in women $(p<0.05)$. All patients with raised blood pressure were men $(\mathrm{p}<0.05)$ (Table 1).

There were no differences between the groups in terms of gender, mean age, marital status, economic level, place of residence, education, psychiatric disorders in the first and second degree relatives, diabetes in the first degree relatives, cardiovascular and cerebrovascular disorders, age of onset of schizophrenia, duration of disorder, number of hospitalizations, premorbid history, antipsychotic treatment group (atypical, classical, atypical+classical), duration of last treatment and smoking ( $p>0.05$ ) (Table 2). We detected MetS in $19.4 \%, 31.8 \%, 28.6 \%$, and $37.5 \%$ of the subjects in 19-29, 30-39, 40-49, 50-59years age groups, respectively.

There were no differences between the groups regarding schizophrenia subtype and symptoms ( $p>0.05)$ (Table 3).

\section{DISCUSSION}

MetS prevalence in patients with schizophrenia per IDF criteria varies between 13.4\%-69.3\% (1,11-31). 
One of the most important causes for MetS in patients with schizophrenia is antipsychotic treatment. MetS is not common in patients who are not on antipsychotics. Padmavati and associates (47), reported MetS prevalence as $3.9 \%$, and Patel and associates as $4.3 \%$ (11) in antipsychotic naive patients with schizophrenia. In our study, consistent with previous studies, we found MetS in $27 \%$ of the subjects who were using antipsychotic drugs for at least three months.

In a large adult population sample representing all geographical regions of Turkey, Sanisoglu and associates (48), reported MetS prevalence in all country as $17.9 \%$ and $14.2 \%$ in Black Sea region. In our study, which was conducted in Black Sea region, the prevalence of MetS we found in patients with schizophrenia (27\%) was almost two times higher than the figure reported by Sanisoglu and colleagues (48) in the general population sample (14.2\%). In another study, we found that MetS prevalence per IDF criteria was 32\% among chronic inpatients hospitalized in the regional mental health hospital (25). These results indicate that MetS is an important health problem in patients with schizophrenia in our region.

In a study conducted in our country (METSAR), it was reported that MetS incidence increased with age in the adult population 20 years and over (age 20-29 $10.2 \%$, age $30-3926.8 \%$, age $40-4944.4 \%$, age $50-59$ $54.7 \%$ ) (49). In our study, we detected MetS in $19.4 \%$, $31.8 \%, 28.6 \%$, and $37.5 \%$ of the subjects in $19-29$, 30-39, 40-49, 50-59 years age groups, respectively. MetS prevalence in our patients in 19-29 age group was higher than reported in the METSAR study $(10.2 \%$ vs $19.4 \%$ ), on the other hand, our rates were lower in the $40-49$ and $50-59$ years age groups $(44.4 \%$ vs $28.6 \%$ and $54.7 \%$ vs $37.5 \%)$. Similarly, in another study, MetS rate in the 20-29 years age group was found to be higher than METSAR rates (10.2\% vs $22.4 \%$ ) (27). When increased prevalence of MetS with age in the population sample was taken into account, it was interesting to observe that MetS was more common than the population in our young patients with schizophrenia while it was less common than the general population in older patients. MetS in young patients with schizophrenia may lead to CVD in young ages.
Therefore, it is important to follow MetS in the young age group.

Raised waist circumference was the most common MetS criteria (65.8\%). This finding was consistent with the literature (1,17,24,27-29,35-40). In consistent with previous studies, waist circumference was larger in women $(17,32)$. De Hert and associates (50) reported that the most common MetS criteria among first episode, (<1.5 years), new onset (1.5-10 years), subchronic (10-20 years) and chronic ( $>20$ years) schizophrenia patients was waist circumference. These findings suggest that waist circumference is an important criteria to follow the patients. The least common criteria was increased blood pressure (10.8\%). All 12 patients with increased blood pressure were men.

Several studies did not find gender differences between schizophrenia patients with or without MetS $(1,14,16,19,27,28,32,33)$. However, there are other studies which reported increased MetS prevalence in women $(17,24,25,28-30,35)$ or men (26). Our results supported those studies which did not find gender differences. There was no difference in marital status in our study. This was contrary to Pallawa and colleagues (31) results indicating that MetS was more common in married patients with schizophrenia. While several studies found MetS to be more common in older patients $(1,17,23,27,29-31,35)$, fewer studies reported no age differences $(26,32,36)$. We did not find any age difference. Pallawa and associates (31) reported higher education in schizophrenia patients with MetS. Grover and colleagues (28) and Oyeckin and associates (32) argued that there was no difference regarding education. Our study was consistent with the two latter studies. Besides, we did not find any difference in terms of economical level and place of residence. Studies with bigger samples are necessary to detect sociodemographical features of patients with MetS.

Previous studies reported no differences in family history of schizophrenic disorder (27) and cerebrovascular disorders (29) in patients with MetS. In our study, we did not find any difference in family history of psychiatric disorders in the first and second 
degree relatives and cerebrovascular disorders in the first degree relatives. While there is one study suggesting that family history of diabetes is more common (31), several studies have not supported this finding $(19,24,27,29,32,36)$. Our findings support the latter studies. Hägg and associates (33) reported increased CVDs in families of patients with MetS, however, two other studies did not find that association $(27,36)$. We did not detect any difference regarding CVD.

We did not find any association between schizophrenia subtypes and MetS. This was consistent with the literature $(29,32)$. Besides, we did not find any difference regarding schizophrenia symptoms in patients with or without MetS. To the best of our knowledge, this is the first study to evaluate the association of MetS with schizophrenia symptoms. It can be argued that there is no association between MetS and schizophrenia symptoms or subtypes.

While Srisurapanont and colleagues (19) and Kaya and associates (26) did not find any difference regarding age of onset; Yazici and colleagues (27), reported older age of onset in schizophrenia patients with MetS. Our study was consistent with the first two studies. While several studies reported longer duration of illness in schizophrenia patients with MetS $(1,24,29,31,34)$, other studies did not $(26,27,32)$. We did not find any difference in terms of duration of illness. Sugawara and colleagues (15) reported higher number of hospitalizations in schizophrenia patients with MetS. However, similar to our study, two other studies did not find such an association $(19,32)$. Smoking was not different between schizophrenia patients with or without MetS $(24,26,27,32,36)$. This was consistent with our results. Besides, we did find any difference regarding premorbid history. Antipsychotic use is one of the most important causes of MetS in patients with schizophrenia. In our study, there were no differences in terms of antipsychotic group (typical, atypical, typical+atypical combination).

In conclusion, MetS is an important problem in schizophrenia patients using antipsychotics. Waist circumference may be an important criteria in clinical follow-up. There are conflicting results in the literature on the association of MetS and sociodemographical and clinical variables. More studies are necessary to enlight this issue. It seems like MetS is not associated with schizophrenia symptoms or subtypes.

\section{REFERENCES}

1. Mitchell AJ, Vancampfort D, Sweers K, van Winkel R, Yu W, De Hert M. Prevalence of metabolic syndrome and metabolic abnormalities in schizophrenia and related disorders-a systematic review and meta-analysis. Schizophr Bull 2013; 39:306-318.

2. Riordan HJ, Antonini P, Murphy MF. Atypical antipsychotics and metabolic syndrome in patients with schizophrenia: risk factors, monitoring, and healthcare implications. American Health \& Drug Benefits 2011; 4:292-302.

3. Wagenknecht LE, Langefeld CD, Scherzinger AL, Norris JM, Haffner SM, Saad MF, Bergman RN. Insulin sensitivity, insulin secretion, and abdominal fat: the insulin resistance atherosclerosis study (IRAS) Family study. Diabetes 2003; 52:2490-2496.

4. Holt RI, Peveler RC, Byrne CD. Schizophrenia, the metabolic syndrome and diabetes. Diabet Med 2004; 21:515-523.

5. Gami AS, Witt BJ, Howard DE, Erwin PJ, Gami LA, Somers VK, Montoni VM. Metabolic syndrome and risk of incident cardiovascular events and death: a systematic review and metaanalysis of longitudinal studies. J Am Coll Cardiol 2007; 49:403-414.

6. Kozumplik O, Uzun S, Jakovljević M. Metabolic syndrome in patients with psychotic disorders: diagnostic issues, comorbidity and side effects of antipsychotics. Psychiatr Danub 2010; 22:6974.

7. Meyer JM, Stahl SM. The metabolic syndrome and schizophrenia. Acta Psychiatr Scand 2009; 119:4-14.

8. Reaven GM. Banting lecture 1988. Role of insulin resistance in human disease. Diabetes 1988; 37:1595-1607.

9. Meyer J, Koro CE, L'Italien GJ. The metabolic syndrome and schizophrenia: a review. Int Rev Psychiatry 2005; 17:173-180.

10. Keltner NL. Biological perspectives. Metabolic syndrome: schizophrenia and atypical antipsychotics. Perspect Psychiatr Care 2006;42:204-207.

11. Patel JK, Buckley PF, Woolson S, Hamer RM, McEvoy JP, Perkins DO, Lieberman JA; CAFE Investigators. Metabolic profiles of second-generation antipsychotics in early psychosis: findings from the CAFE study. Schizophr Res 2009; 111:9-16. 
12. Falissard B, Mauri M, Shaw K, Wetterling T, Doble A, Giudicelli A, De Hert M. The METEOR study: frequency of metabolic disorders in patients with schizophrenia. Focus on first and second generation and level of risk of antipsychotic drugs. Int Clin Psychopharmacol 2011; 26:291-302.

13. Subashini R, Deepa M, Padmavati R, Thara R, Mohan V. Prevalence of diabetes, obesity and metabolic syndrome in subjects with and without schizophrenia (CURES-104). J Postgrad Med 2011; 57:272-277.

14. Sugawara N, Yasui-Furukori N, Sato Y, Umeda T, Kishida I, Yamashita H, Saito M, Furukori H, Nakagami T, Hatakeyama M, Nakaji S, Kaneko S. Prevalence of metabolic syndrome among patients with schizophrenia in Japan. Schizophr Res 2010; 123:244-250.

15. Sugawara N, Yasui-Furukori N, Sato Y, Kishida I, Yamashita H, Saito M, Furukori H, Nakagami T, Hatakeyama M, Kaneko S. Comparison of prevalence of metabolic syndrome in hospital and community-based Japanese patients with schizophrenia. Ann Gen Psychiatry 2011;10:21.

16. Kaponen HJ, Hakko HH, Saari KM, Lindeman SM, Karvonen KM, İsohanni MK, Lauren LH, Savolainen MJ, Järvelin MR. The prevalence and predictive value of individual criteria for metabolic syndrome in schizophrenia: a Northern Finland 1966 birth cohort. World J Biol Psychiatry 2010; 11:262-267.

17. De Hert M, van Vinkel R, Van Eyck D, Hanssens L, Wampers M, Scheen A, Peuskens J. Prevalence of the metabolic syndrome in patients with schizophrenia treated with antipsychotic medication. Schizophr Res 2006; 83:87-93.

18. Tirupati S, Chua LE. Body mass index as a screening test for metabolic syndrome in schizophrenia and schizoaffective disorders. Australas Psychiatry 2007; 15:470-473.

19. Srisurapanont M, Likhitsathian S, Boonyanaruthee V, Charnsilp C, Jarusuraisin N. Metabolic syndrome in Thai schizophrenic patients: a naturalistic one-year follow up study. BMC 2007; 7:14.

20. Kurt E, Altinbas K, Alatas G, Ozver I. Metabolic syndrome prevalence among schizophrenic patients treated in chronic inpatient clinics. Psychiatry in Türkiye 2007; 9:141-145 (in Turkish).

21. Saddichha S, Ameen S, Akhtar S. Incidence of new onset metabolic syndrome with atypical antipsychotics in first episode schizophrenia: a six-week prospective study in Indian female patients. Schizophr Res 2007; 95:247.

22. Saddichha S, Maniunatha N, Ameen S, Akhtar S. Metabolic syndrome in first episode schizophrenia: a randomized doubleblind controlled, short-term prospective study. Schizophr Res 2008; 101:266-272.
23. Cerit C, Ozten E, Yildiz M. The prevalence of metabolic syndrome and related factors in patients with schizophrenia. Turk Psikiyatri Derg 2008; 19:124-132.

24. Cerit C, Vural M, Bos Gelmez SU, Ozten E, Aker AT, Yildiz M. Metabolic syndrome with different antipsychotics: a multicentre cross-sectional study. Psychopharmacol Bull 2010; 43:22-236.

25. Boke O, Aker S, Sarisoy G, Saricicek EB, Sahin AR. Prevalence of metabolic syndrome among inpatients with schizophrenia. Int J Psychiatry Med 2008; 38:103-112.

26. Kaya MC, Virit O, Altindag A, Selek S, Bulbul F, Bulut M, Savas HA. Prevalence of metabolic syndrome, characteristics of metabolic syndrome and relationship with the antipsychotics used in schizophrenia. Archives of Neuropsychiatry 2009; 46:1318 (in Turkish).

27. Yazici MK, Anil Yagcioglu AE, Ertugrul A, Eni N, Karahan S, Karaagaoglu E, Tokgozoglu SL. The prevalence and clinical correlates of metabolic syndrome in patients with schizophrenia: findings from a cohort in Turkey. Eur Arch Psychiatry Clin Neurosci 2011; 261:69-78.

28. Grover S, Aggarwal M, Dutt A, Chakrabarti S, Avasthi A, Kulhara P, Somaiya M, Malhotra N, Chauhan N. Prevalence of metabolic syndrome in patients with schizophrenia in India. Psychiatry Res 2012; 200: 1035-1037.

29. Guveli H, Ilnem MC, Yener F, Karamustafalioglu N, Ipekcioglu D, Abanoz Z. The frequency of metabolic syndrome in schizoprenia patients using antipsychotic medication and related factors. New Symposium 2011; 49:67-76 (in Turkish).

30. Bou Khalil R. Atypical antipsychotic drugs, schizophrenia, and metabolic syndrome in non-euro-american societies. Clin Neuropharmacol 2012; 35:141-147.

31. Pallava A, Chadda RK, Sood M, Lakshmy R. Metabolic syndrome in schizophrenia: a comparative study of antipsychotic-free/ naive and antipsychotic-treated patients from India. Nord J Psychiatry 2012; 66:215-221.

32. Oyeckin DG. The frequency of metabolic syndrome in patients with schizophrenia and schizoaffective disorder. Anatolian Journal of Psychiatry 2009; 10:26-33 (in Turkish).

33. Hägg S, Lindblom Y, Mjörndal T, Adolfsson R. High prevalence of the metabolic syndrome among a Swedish cohort of patients with schizophrenia. Int Clin Psychopharmacol 2006; 21:93-98.

34. Bai YM, Chen TT, Yang WS, Chi YC, Lin CC, Liou YJ, Wang YC, Su TP, Chou P, Chen JY. Association of adiponectin and metabolic syndrome among patients taking atypical antipsychotics for schizophrenia: a cohort study. Schizophr Res 2009; 111:1-8. 
35. Huang MC, Lu ML, Tsai CJ, Chen PY, Chiu CC, Jian DL, Lin KM, Chen $\mathrm{CH}$. Prevalence of metabolic syndrome among patients with schizophrenia or schizoaffective disorder in Taiwan. Acta Psychiatr Scand 2009; 120:274-280.

36. Kato MM, Currier MB, Gomez CM, Hall L, Gonzalez-Blanco M. Prevalence of metabolic syndrome in hispanic and non-hispanic patients with schizophrenia. Prim Care Companion J Clin Psychiatry 2004; 6:74-77.

37. Straker D, Correll CU, Kramer-Ginsberg E, Abdulhamid N, Koshy F, Rubens E, Saint-Vil R, Kane JM, Manu P. Cost-effective screening for the metabolic syndrome in patients treated with second-generation antipsychotic medications. Am J Psychiatry 2005; 162:1217-1221.

38. Kang SH, Kim KH, Kang GY, Lee KH, Kim KK, Soh M, Ahn KJ, Kim SH, Lee JI. Cross-sectional prevalence of metabolic syndrome in Korean patients with schizophrenia. Schizophr Res 2011; 128:179-181.

39. Kagal UA, Torgal SS, Patil NM, Malleshappa A. Prevalence of the metabolic syndrome in schizophrenic patients receiving secondgeneration antipsychotic agents--a cross-sectional study. Pharm Pract 2012; 25:368-373.

40. De Hert M, Schreurs V, Vancampfort D, VAN Winkel R. Metabolic syndrome in people with schizophrenia: a review. World Psychiatry 2009; 8:15-22.

41. Gautam S, Meena PS. Drug-emergent metabolic syndrome in patients with schizophrenia receiving atypical (secondgeneration) antipsychotics. Indian J Psychiatry 2011; 53:128-133.

42. Correll CU, Frederickson AM, Kane JM, Manu P. Does antipsychotic polypharmacy increase the risk for metabolic syndrome? Schizophr Res 2007; 89:91-100.
43. Koroglu E. Psikiyatride Hastalıkların Tanımlanması Ve Sinıflandırılması Elkitabı, Gözden Geçirilmiş Dördüncü Baskı (DSM-IV-TR). Amerikan Psikiyatri Birliği, Washington DC, 2000'den çeviri, Hekimler Yayın Birliği. Ankara, 2001 (DSM-IVTR in Turkish).

44. Kay SR, Fiszbein A, Opler LA. The positive and negative syndrome scale (PANSS) for schizophrenia. Schizophr Bull 1987; 13: 261-275.

45. Kostakoglu AE, Batur S, Tiryaki A, Gogus A. Reliability and validity of the Turkish version of the Positive and Negative Syndrome Scale (PANSS). Turkish Journal of Psychology 1999; 14:23-32 (in Turkish).

46. Alberti KG, Zimmet P, Shaw J; IDF Epidemiology Task Force Consensus Group. The metabolic syndrome-a new worldwide definition. Lancet 2005; 366:1059-1062.

47. Padmavati R, McCreadie RG, Tirupati S. Low prevalence of obesity and metabolic syndrome in never-treated chronic schizophrenia. Schizophr Res 2010; 121:199-202.

48. Sanisoglu SY, Oktenli C, Hasimi A, Yokusoglu M, Ugurlu M. Prevalence of metabolic syndrome-related disorders in a large adult population in Turkey. BMC Public Health 2006; 6:92.

49. Kozan O, Oguz A, Abaci A, Erol C, Ongen Z, Temizhan A, Celik S. Prevalence of the metabolic syndrome among Turkish adults. Eur J Clin Nutr 2007; 61:548-553.

50. De Hert M, van Winkel R, Van Eyck D, Hanssens L, Wampers M, Scheen A, Peuskens J. Prevalence of diabetes, metabolic syndrome and metabolic abnormalities in schizophrenia over the course of the illness: a cross-sectional study. Clin Pract Epidemiol Ment Health 2006; 2:14. 